\title{
THE EVALUATION OF CULTURE MEDIA FOR THE ISOLATION OF SALMONELLAE FROM FAECES
}

\author{
By H. WILliams SMITH, Ph.D., M.Sc., M.R.C.V.S., DiP.BaCt. \\ From the Livestock Research Station, Animal Health Trust, \\ Houghton Grange, Huntingdon
}

When comparing the frequency with which salmonellae were isolated from the faeces of different species of animals in two recent surveys (Cruickshank \& Williams Smith, 1949; Williams Smith \& Buxton, 1951) it was thought possible that the variation in the chemical and bacterial content of the faeces of the different species might have rendered the isolation of salmonellae more difficult from some species than from others. In this respect it was borne in mind that the culture media used, selenite and tetrathionate broth, were evolved for the isolation of salmonellae, primarily Salmonella typhi, from the faeces of human beings.

Most of the studies on the use of different media for the isolation of salmonellae from faeces have been carried out by comparing them under practical conditions. This, of course, does not result in an absolute expression of the sensitivity of the media. Work on this subject has been undertaken mainly by adding known amounts of cultures of salmonellae to faeces and then endeavouring to recover them by means of the culture medium under test. It can be argued, however, that cultures are adapted to growing in artificial media, and, consequently, an inaccurate result may be obtained.

The purpose of this communication is to report on the sensitivity of selenite, tetrathionate and other media for isolating salmonellae from the faeces of different species of animals to which had been added suitable dilutions of tissue fluids of animals that had died from salmonella infection. The numbers of viable salmonellae in these dilutions could be accurately determined.

\section{MATERIALS AND METHODS \\ Source of faecal specimens}

Faecal specimens were obtained from man, horse, cow, sheep, pig, dog, chicken, duck and turkey. In order to avoid individual differences within each species, where possible, only one animal was sampled in any one herd, flock or other unit. Specimens were always used for experiment within a few days of collection.

\section{Source and preparation of salmonella-infected material}

Suitable organs from animals that had died from salmonella infection were examined to determine whether salmonellae were the only bacteria obtainable from them. If that was so, the organs were ground in a sterile mortar containing a small amount of sterile distilled water. The suspension was then allowed to stand, or lightly centrifuged. Serial tenfold dilutions were then made of the 
supernatant fluid in sterile distilled water containing $0.1 \%$ bovine albumen (Fenner, Martin \& Pierce, 1949) and bacterial counts were made on nutrient agar by the method of Miles \& Misra (1938). Bovine albumen was used after comparing a number of commonly used dilution fluids because it was found to be the best for maintaining small numbers of salmonellae without any apparent decrease in the viable count. Suitable dilutions were then made containing the desired number of bacteria; repeat counts were made on these at the same time as they were used for carrying out each experiment.

Tissue fluids from the following organs were used: ovum of duck (Salm. typhimurium), liver of mouse (Salm. thompson), liver of cow (Salm. dublin), liver of pig (Salm. cholerae-suis), liver of chicken (Salm. gallinarum) and (Salm. pullorum).

\section{Liquid enrichment media}

Selenite-F medium. A modification of the original medium of Leifson (1936) was used, the lactose being replaced by mannitol (Hobbs \& Allison, 1945).

Tetrathionate broth. This was prepared according to Method A of Rolfe (1946), but the brilliant green was omitted. Initial titrations were carried out as suggested by Rolfe, and the optimum amounts of the iodine and sodium thiosulphate solutions were found to be 4.5 and $9.0 \mathrm{ml}$. respectively per $100 \mathrm{ml}$. of broth. These amounts, unless otherwise stated, were used throughout.

Cacotheline broth. This was prepared as described by Jones \& Handley (1945).

Liquid Wilson and Blair medium. The modification devised by Hobbs \& Allison (1945) of the original medium of Wilson \& Blair (1931) was employed.

Liquid desoxycholate-citrate medium. Hynes's (1942) modification of the original formula of Leifson (1935) was used.

Brilliant green peptone water. This was prepared simply by adding brilliant green to peptone water to give a final concentration of 1 in 100,000.

All enrichment media were used in $10 \mathrm{ml}$. amounts.

\section{Solid media}

Desoxycholate-citrate-agar. Hynes's (1942) modification of Leifson's desoxycholate-citrate-agar with the addition of $1 \%$ sucrose and $1 \%$ salicin (Haines, Elliot \& Tomlinson, 1947) was used.

Wilson and Blair bismuth sulphite agar. Preliminary experiments were carried out using this medium prepared according to different formulae, but, because of variations found even between batches prepared according to the same formula, it was decided to use the dehydrated Difco brand of this medium.

Brilliant green agar. This was prepared according to the formula of Slavin (1943), a final concentration of 1:20,000 brilliant green being found the most suitable.

\section{Method of testing}

Enrichment media. Specimens of faeces obtained from different species of animals and having a volume of about $1 \mathrm{ml}$. were emulsified in tubes of enrichment media. A dilution of infected tissue fluid that contained the desired number of salmonellae was added to each tube, the tube then being well shaken. The enrich- 
ment media were incubated for $24 \mathrm{hr}$. at $37^{\circ} \mathrm{C}$. and then streaked on to plates of solid medium, half of the plate being used for each specimen. These plates were incubated for $48 \mathrm{hr}$. at $37^{\circ} \mathrm{C}$. and examined. Colonies resembling salmonellae were tested for side-agglutination with anti-O serum to the species of salmonella with which the enrichment media had been inoculated.

The number of salmonellae added to each tube of enrichment medium at the commencement of each series of tests was, on average, four. When salmonellae were not recovered in any enrichment medium from any specimen of faeces to which they had been added, the experiment was repeated, using a similar volume of the particular faecal specimen and an amount of infected tissue fluid containing twice the number of salmonellae previously used. This process of 'doubling-up' was continued until all samples yielded salmonellae on culture.

Whenever possible, comparative tests were made on the same day, so that the conditions of experiment remained constant.

Direct plating. The technique, with some slight modification, was similar to that used for the enrichment media. The same volume of faeces was used, but a small amount of distilled water was added so that the salmonellae could be well distributed throughout the specimen. A large loopful of each specimen was then streaked on to plates of different media. The plates were examined after $48 \mathrm{hr}$. incubation at $37^{\circ} \mathrm{C}$.

\section{RESULTS}

It is difficult to give a concise and accurate account of this work merely by a numerical consideration of the results obtained. For example, specimens from which salmonellae were recovered in pure plentiful culture are not differentiated from those which were found to be positive only after a very careful examination of the different colonies that grew-a point of considerable practical importance. Consequently, I have presented below only those results which seem to me to be significant after consideration of such things as abundance of growth, consistency of cultural appearance and so on; even when numerical differences quoted are small, it may be taken that I hold them to be real and substantially reproducible. The reader will probably think that higher significance attaches to some results than to others, for the numerical differences observed in some experiments were much greater than in others: and in so thinking, the reader will probably be right. Nevertheless, I have presented only those results which I believe to be in general reproducible.

The recovery of Salmonella dublin, typhi-murium and thompson from faeces using selenite and tetrathionate media

The recovery rate of Salm. dublin from 180 specimens of human, dog, horse, cow, sheep, pig, chicken, duck and turkey faeces (twenty specimens per species), to which had been added tissue fluid containing an average of four Salm. dublin bacteria, by means of selenite and tetrathionate media, is shown in Table 1. The solid medium used for culturing from these enrichment media was desoxycholate-citrate-agar. The results for Salm. typhi-murium and thompson are shown in Tables 2 and 3 respectively. The only difference in the conditions of the three 
experiments was that different faecal specimens were used in each. The results of the three experiments are summarized in Table 4. Of a total of 540 specimens infected with approximately four salmonellae, 386 were shown to be positive by means of selenite, 372 by tetrathionate and 445 by one or other of these media. When negative specimens were retested using approximately eight instead of

Table 1. The number of positive results obtained using selenite and tetrathionate media following the addition of tissue fluid containing approximately four Salmonella dublin bacteria to specimens of faeces of different animals

Origin of faecal specimens
(20 per species)
Horse
Sheep
Man
Cow
Chicken
Pig
Turkey
Dog
Duck
Total (of 180 specimens)

\begin{tabular}{ccc}
\multicolumn{3}{c}{ No. positive by } \\
$15(19)$ & $17(20)$ & $18(20)$ \\
$14(19)$ & $14(19)$ & $19(20)$ \\
$11(16)$ & $14(16)$ & $16(20)$ \\
$8(13)$ & $5(11)$ & $9(14)$ \\
$10(16)$ & $2(12)$ & $11(19)$ \\
$10(16)$ & $10(12)$ & $16(20)$ \\
$5(9)$ & $3(6)$ & $5(10)$ \\
$4(12)$ & $10(18)$ & $13(19)$ \\
$1(12)$ & $0(7)$ & $1(15)$ \\
$78(132)$ & $75(121)$ & $108(157)$
\end{tabular}

Both enrichment media were cultured on to desoxycholate-citrate-agar.

The figures in parentheses represent the total positive results obtained after the negative specimens had been repeated using an inoculum of eight Salm. dublin bacteria. All specimens, except two, were positive when 100 bacteria were used.

Table 2. The number of positive results obtained using selenite and tetrathionate media following the addition of tissue fluid containing approximately four Salmonella typhi-murium bacteria to specimens of faeces of different animals

Origin of faecal specimens (20 per species)

Horse
Sheep
Man
Cow
Chicken
Pig
Turkey
Dog
Duck
Total (of 180 specimens)

No. positive by

$\begin{array}{ccc}\text { Selenite } & \text { Tetrathionate } & \text { Both media } \\ 19(20) & 20(20) & 20(20) \\ 19(20) & 19(20) & 20(20) \\ 18(20) & 19(20) & 20(20) \\ 16(20) & 9(19) & 16(20) \\ 14(18) & 14(18) & 15(19) \\ 12(18) & 12(19) & 16(19) \\ 16(20) & 14(20) & 18(20) \\ 15(19) & 17(20) & 18(20) \\ 16(20) & 13(19) & 17(20) \\ 145(175) & 137(175) & 160(178)\end{array}$

Both enrichment media were cultured on to desoxycholate-citrate-agar.

The figures in parentheses represent the total positive results obtained after the negative specimens had been repeated using eight Salm. typhi-murium bacteria.

All specimens were positive when sixteen bacteria were used.

four bacteria the figures were 486,475 and 515 respectively. All the specimens were positive in the case of Salm. typhi-murium and Salm. thompson when the inoculum was increased to sixteen bacteria; only two specimen s were negative when the inoculum in the Salm. dublin experiments was 100 salmonellae. Selenite was considered to be slightly superior to tetrathionate medium, since, apart from 
the fact that a few more specimens were shown to be positive by the use of this medium, non-fermenting colonies which were not salmonellae appeared more frequently after tetrathionate enrichment. These tended to obscure the salmonella colonies and rendered the examination more time-consuming.

Table 3. The number of positive results obtained using selenite and tetrathionate media following the addition of tissue fuid containing approximately four Salmonella thompson bacteria to specimens of faeces of different animals

Origin of faecal specimens (20 per species)

Horse
Sheep
Man
Cow
Chicken
Pig
Turkey
Dog
Duck
Total (of 180 specimens)

\begin{tabular}{ccc}
\multicolumn{3}{c}{ No. positive by } \\
Selenite & Tetrathionate & Both media \\
$19(20)$ & $17(20)$ & $19(20)$ \\
$20(20)$ & $20(20)$ & $20(20)$ \\
$17(19)$ & $19(20)$ & $20(20)$ \\
$20(20)$ & $19(20)$ & $20(20)$ \\
$18(20)$ & $16(19)$ & $20(20)$ \\
$17(20)$ & $20(20)$ & $20(20)$ \\
$18(20)$ & $16(20)$ & $19(20)$ \\
$18(20)$ & $19(20)$ & $19(20)$ \\
$16(20)$ & $14(20)$ & $20(20)$ \\
$163(179)$ & $160(179)$ & $177(180)$
\end{tabular}

Both enrichment media were cultured on to desoxycholate-citrate-agar.

The figures in parentheses represent the total results obtained after the negative specimens had been repeated using eight Salm. thompson bacteria.

All specimens were positive when sixteen bacteria were used.

Table 4. The total number of positive results when Salmonella dublin, Salm. typhimurium or Salm. thompson were used (summarized from Tables 1, 2 and 3)

$\begin{aligned} & \text { Origin of faecal specimens } \\ & \quad(60 \text { per species) }\end{aligned}$
Horse
Sheep
Man
Cow
Chicken
Pig
Turkey
Dog
Duck
Total (of 540 specimens)

\begin{tabular}{ccc}
\multicolumn{3}{c}{ No. positive by } \\
$\overbrace{\text { Selenite }}$ & Tetrathionate & Both media \\
$53(59)$ & $54(60)$ & $57(60)$ \\
$53(59)$ & $53(59)$ & $59(60)$ \\
$46(55)$ & $52(56)$ & $56(60)$ \\
$44(53)$ & $33(50)$ & $45(54)$ \\
$42(54)$ & $32(49)$ & $46(58)$ \\
$39(54)$ & $42(51)$ & $52(59)$ \\
$39(49)$ & $33(46)$ & $42(50)$ \\
$37(51)$ & $46(58)$ & $50(59)$ \\
$33(52)$ & $27(46)$ & $38(55)$ \\
$386(486)$ & $372(475)$ & $445(515)$
\end{tabular}

Both enrichment media were cultured on to desoxycholate-citrate-agar.

The figures in parentheses represent the total positive results obtained after the negative specimens had been repeated using eight salmonella bacteria.

Salm. dublin was much more difficult to isolate than Salm. typhi-murium, and the latter more difficult than Salm. thompson; of 180 specimens inoculated with four Salm. dublin bacteria only 78 were shown to be positive by means of selenite, 75 by means of tetrathionate and 108 by one or other of these media. The corresponding figures for Salm. typhi-murium, however, were 145, 137 and 160, and for Salm. thompson 163, 160 and 177.

It was more difficult to recover small inocula from the faeces of some species 
of animals than from others. For example, using four Salm. dublin bacteria, only one of 20 faecal specimens from ducks was positive by means of selenite and none by tetrathionate, but the corresponding figures for horse faeces were 15 and 17 respectively (Table 1 ). The order of ease of recovery from different animal faeces (60 specimens per species) which had been inoculated with either four Salm. dublin, typhi-murium, or thompson bacteria was horse (53), sheep (53), man (46), cow (44), chicken (42), pig (39), turkey (39), dog (37) and duck (33) in the case of selenite medium. A somewhat similar order found with tetrathionate broth was horse (54), sheep (53), man (52), dog (46), pig (42), cow (33), turkey (33), chicken (32) and duck (27). Many of these differences were more significant than the figures suggest, and it is probable that if the experiment was repeated the order of ease of recovery with both media would not be substantially altered. For example, most of the positive specimens of horse and sheep faeces yielded a pure and plentiful culture of salmonellae after both selenite and tetrathionate enrichment, a phenomenon which occurred much less frequently with the positive specimens from the other species, particularly those placed towards the end of both lists. When the species were considered separately selenite was superior to tetrathionate with cow faeces, giving $44 / 60$ positive recoveries against $33 / 60$, with four bacteria inoculated, and chicken faeces (42 against 33), while the reverse was true with dog faeces (37 against 46); slight differences only were noted in the other species (Table 4).

The Salm. dublin experiment was repeated under exactly the same conditions except that four bacteria from a primary culture of the tissue fluid were used as the salmonella inoculum. The recovery figures from 180 specimens were 119 for selenite, 112 for tetrathionate and 150 for both media compared with 78, 75 and 108 when tissue fluid containing the same number of bacteria were used (Table 1).

The recovery of Salmonella dublin, typhi-murium and thompson from faeces by direct plate culture

An initial experiment was carried out using specimens of faeces to which had been added dilutions of tissue fluid containing either 20, 200 or $2000 \mathrm{Salm}$. dublin, typhi-murium or thompson bacteria. Culture of these specimens on desoxycholatecitrate-agar and Wilson and Blair bismuth sulphite agar revealed that salmonellae could only be recovered from some of those containing 2000 viable cells.

Tissue fluid containing approximately $2000 \mathrm{Salm}$. dublin bacteria was added to five specimens of faeces from each of the nine species of animals, and these were then cultured on desoxycholate-citrate-agar and Wilson and Blair media. The procedure was repeated using 20,000 bacteria. The whole experiment was then repeated under exactly the same conditions using tissue fluids containing Salm. typhi-murium and thompson. The results for the three salmonella species are grouped together in Table 5 because no significant difference was found between them. With an inoculum of 2000 salmonellae, 37 of the 135 infected specimens were positive on Wilson and Blair medium and 43 on desoxycholatecitrate-agar. The corresponding figures for 20,000 bacteria were 100 and 72 , showing that Wilson and Blair medium was superior when the large inoculum 
was used. However, as with selenite and tetrathionate media, a considerable number of specimens were shown to be positive by one of the media but not by the other.

As with selenite and tetrathionate media, it was easier to recover salmonellae by direct culture of the faeces of some species than of others. Once again salmonellae were most easily recovered from horse faeces. Recovery from sheep and human faeces was much more difficult, particularly when desoxycholatecitrate-agar was used, but was easier from cow faeces.

Table 5. The number of positive results obtained by the direct culture on solid media of faeces to which had been added tissue fuids containing Salmonella dublin, typhi-murium or thompson

Approx. no. of Salm. dublin, typhi-murium or thompson in tissue fluid added to each specimen

\begin{tabular}{|c|c|c|c|c|}
\hline \multirow[b]{2}{*}{$\begin{array}{l}\text { Origin of faecal speci- } \\
\text { mens (15 per species) }\end{array}$} & \multicolumn{2}{|c|}{$\begin{array}{l}\text { ' } 2000 \\
\text { No. positive by }\end{array}$} & \multicolumn{2}{|c|}{$\begin{array}{l}20,000 \\
\text { No. positive by }\end{array}$} \\
\hline & 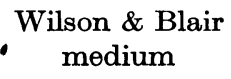 & $\begin{array}{l}\text { Desoxycholate- } \\
\text { citrate-agar }\end{array}$ & $\begin{array}{l}\text { Wilson \& Blair } \\
\text { medium }\end{array}$ & $\begin{array}{l}\text { Desoxycholate- } \\
\text { citrate-agar }\end{array}$ \\
\hline Horse & 9 & 14 & 15 & 15 \\
\hline Cow & 7 & 9 & 14 & 14 \\
\hline Dog & 7 & 5 & 10 & 6 \\
\hline Duck & 3 & 6 & 12 & 12 \\
\hline Chicken & 3 & 4 & 10 & 8 \\
\hline Pig & 3 & 1 & 10 & 5 \\
\hline Sheөp & 2 & 1 & 10 & 3 \\
\hline Man & 3 & 2 & 8 & 3 \\
\hline Turkey & 0 & 1 & 11 & 6 \\
\hline Total (of 135 specimens) & 37 & 43 & 100 & 72 \\
\hline
\end{tabular}

One of the three salmonella types was added to five faecal specimens from each species.

The combined inhibitory effect of selenite medium and Wilson and Blair bismuth sulphite agar

Originally it was intended to use both Wilson and Blair medium and desoxycholate-citrate-agar for culturing from enrichment media. However, the combined inhibitory effect of selenite and Wilson and Blair medium when fluid from selenite medium known to contain salmonellae was streaked on to the Wilson and Blair medium was such that often no salmonella colonies appeared after incubation. For example, thirty specimens of sheep faeces together with tissue fluid containing approximately eight Salm. typhi-murium bacteria were inoculated into selenite and also tetrathionate media and then cultured on to Wilson and Blair medium and desoxycholate-citrate-agar. All the specimens incubated in tetrathionate yielded a prolific growth of salmonellae on desoxycholate-citrate-agar and on Wilson and Blair medium, no evidence of any inhibition being shown on either series of plates. Salmonellae were recovered plentifully from twenty-nine of the thirty specimens incubated in selenite medium when cultured on to desoxycholate-citrate-agar, but only twelve were positive on Wilson and Blair medium.

Twenty-seven strains of salmonellae representing eighteen different species were grown in selenite and tetrathionate media for $18 \mathrm{hr}$. Each culture was then 
streaked, in the usual way, over half the surface of a plate of Wilson and Blair medium which was then incubated for $48 \mathrm{hr}$. The twenty-seven cultures in tetrathionate medium yielded a profuse growth of salmonella colonies without any sign of inhibition. Two selenite cultures of Salm. typhi, one of Salm. thompson, two of Salm. enteritidis, one of Salm. concord, and one of Salm. montevideo grew quite well when cultured on Wilson and Blair medium. One culture of Salm. thompson, one of Salm. derby, two of Salm. paratyphi B and one of Salm. schwartzengrund yielded a few salmonella colonies at the end of the inoculation streak where presumably the concentration of selenite was lowest. The plates inoculated with the remaining fifteen cultures were completely negative. These cultures comprised one strain of Salm. para-typhi C, two of Salm. thompson, three of Salm. dublin, one of Salm. enteritidis, one of Salm. anatum, one of Salm. london, one of Salm. meleagridis, four of Salm. typhi-murium and one of Salm. gallinarum.

A small zone of inhibition was sometimes noted on plates of desoxycholatecitrate-agar that had been sown with cultures of salmonellae in selenite medium. This zone was at the commencement of the inoculation area where the concentration of selenite would be greatest. It was never sufficient to mask the presence of any salmonellae in the inoculum.

\section{Comparison of mannitol ard lactose selenite}

Because of the observation of Hobbs \& Allison (1945) that the replacement of lactose in the original medium of Leifson (1936) by mannitol increased the sensitivity of selenite medium for the isolation of Salm. typhi, selenite medium prepared with mannitol was used in this work. However, it was decided to compare both media using the tissue fluids containing Salm. dublin, typhi-murium and thompson and specimens of faeces from different animals. Specimens of human, cow, pig and duck faeces only were used. Dilutions of tissue fluids containing four to eight bacteria of one or other of the three species were used. The enrichment media were cultured on to desoxycholate-citrate-agar. Very little difference was noted between the efficiency of these two media; of 130 specimens examined, 92 were shown to be positive by means of mannitol selenite and 89 by lactose selenite.

The effect of time of incubation of selenite and tetrathionate media on the isolation of salmonellae from lightly infected faeces

Ten tubes of selenite medium were each inoculated with a different specimen of faeces and tissue fluid containing approximately fifteen Salm. dublin bacteria. The procedure was repeated using Salm.typhi-murium and thompson and different specimens of faeces. The experiment was repeated under exactly the same conditions with specimens of faeces from the same animals but this time using tetrathionate medium. Specimens of human, dog, pig, cow, sheep, horse, chicken, turkey and duck faeces were used. The media were incubated at $37^{\circ} \mathrm{C}$, and streaked on to plates of desoxycholate-citrate-agar at $0,6,9,12,15,18,24,30$, 36 and $48 \mathrm{hr}$. Salmonellae were not recovered from any of the specimens before $15 \mathrm{hr}$. (Table 6). The optimum time of incubation in the case of tetrathionate 
was between 24 and $30 \mathrm{hr}$. when salmonellae were recovered from twenty-six of the thirty specimens. The efficiency of this medium then decreased until at $48 \mathrm{hr}$. only nineteen specimens were shown to be positive. In the case of selenite medium the maximum number of twenty-eight positive isolations was obtained at $30 \mathrm{hr}$. but, in contrast to tetrathionate medium, there was no falling off of efficiency at 36 and $48 \mathrm{hr}$.

The above experiment was also repeated at the same time using tetrathionate broth containing $5.5 \mathrm{ml}$. iodine solution and $11.0 \mathrm{ml}$. sodium thiosulphate solution per $100 \mathrm{ml}$. broth instead of 4.5 and $9.0 \mathrm{ml}$. respectively, the amounts indicated by titration as optimum for the broth that was in routine use. This increase in tetrathionate resulted in salmonellae being recovered from only eleven of the thirty specimens as compared with twenty-six when the lesser amount of tetrathionate was

Table 6. The effect of time of incubation of selenite and tetrathionate media on the recovery of salmonellae from lightly infected faeces

\begin{tabular}{ccc}
\multirow{2}{*}{$\begin{array}{c}\text { Time of incubation } \\
\text { in hours }\end{array}$} & \multicolumn{2}{c}{$\begin{array}{c}\text { No. of faecal specimens (out of } 30 \text { ) } \\
\text { positive by }\end{array}$} \\
\cline { 2 - 3 } 0 & 0 & $\begin{array}{c}\text { Selenite } \\
6\end{array}$ \\
9 & 0 & 0 \\
12 & 0 & 0 \\
15 & 0 & 0 \\
18 & 6 & 0 \\
24 & 15 & 8 \\
30 & 26 & 20 \\
36 & 26 & 26 \\
48 & 20 & 28 \\
& 19 & 28
\end{tabular}

Each faecal specimen was inoculated with tissue fluid containing approximately fifteen of either Salm. dublin, typhi-murium, or thompson bacteria. Specimens of human, dog, horse, pig, cow, sheep, chicken, turkey and duck faeces were used.

used, thus confirming Rolfe's (1946) observation of the need to titrate the amounts of iodine and sodium thiosulphate with different batches of nutrient broth. This maximum of eleven positive results was recorded after $30 \mathrm{hr}$. incubation.

Comparison of selenite medium, tetrathionate broth, cacotheline broth, liquid desoxycholate-citrate medium, liquid Wilson and Blair medium and brilliant green peptone water in the isolation of salmonellae from lightly infected faeces

Twenty-seven faecal specimens-three specimens each of human, dog, horse, cow, sheep, pig, chicken, turkey and duck faeces-together with a dilution of tissue fluid containing ten Salm. dublin bacteria were cultured in selenite medium and the recovery rate determined in the usual way. This procedure was repeated using Salm. typhi-murium and thompson making a total of eighty-one faecal specimens, or nine per species. The whole experiment was then repeated under exactly the same conditions and using specimens of the same faeces with the following media: tetrathionate broth, cacotheline broth, liquid desoxycholatecitrate medium, liquid Wilson and Blair medium and brilliant green peptone 
water. Cultures were made on desoxycholate-citrate-agar from all the enrichment media except the liquid desoxycholate-citrate medium; plates of Wilson and Blair medium were used for the latter. Selenite and tetrathionate were greatly superior to the other media for isolating salmonellae from faeces containing small numbers of these bacteria (Table 7). By the use of selenite and tetrathionate media salmonellae were recovered from seventy-three and seventy-two respectively of the eighty-one infected faecal specimens. Twenty-two specimens were shown to be positive by means of brilliant green peptone water, sixteen by cacotheline broth, one by liquid desoxycholate-citrate medium and none by liquid Wilson and Blair medium.

Table 7. Comparison of different liquid enrichment media for the recovery of salmonellae from lightly infected faeces

\begin{tabular}{|c|c|c|c|c|c|c|}
\hline \multirow{2}{*}{$\begin{array}{l}\text { Origin of faecal } \\
\text { specimens } \\
\text { (9 per species) }\end{array}$} & \multicolumn{6}{|c|}{ No. of specimens positive by } \\
\hline & $\begin{array}{l}\text { Selenite } \\
\text { medium }\end{array}$ & $\begin{array}{l}\text { Tetra- } \\
\text { thionate } \\
\text { broth }\end{array}$ & $\begin{array}{c}\text { Brilliant } \\
\text { green } \\
\text { peptone } \\
\text { water }\end{array}$ & $\begin{array}{c}\text { Caco- } \\
\text { theline } \\
\text { broth }\end{array}$ & $\begin{array}{l}\text { Liquid } \\
\text { desoxy- } \\
\text { cholate- } \\
\text { citrate } \\
\text { medium }\end{array}$ & $\begin{array}{l}\text { Liquid } \\
\text { Wilson } \\
\text { and Blair } \\
\text { medium }\end{array}$ \\
\hline Horse & 9 & 9 & 3 & 0 & 0 & 0 \\
\hline Sheep & 9 & 9 & 6 & 2 & 0 & 0 \\
\hline Human & 8 & 8 & 4 & 4 & 0 & 0 \\
\hline Cow & 8 & 8 & 5 & 4 & 0 & 0 \\
\hline Chicken & 8 & 7 & 2 & 0 & 0 & 0 \\
\hline Pig & 8 & 8 & 0 & 0 & 0 & $\mathbf{0}$ \\
\hline Turkey & 7 & 7 & 1 & 0 & 0 & 0 \\
\hline Dog & 8 & 9 & 1 & 6 & 1 & 0 \\
\hline Duck & 8 & 7 & 0 & 0 & 0 & 0 \\
\hline Total (of 81 speci & 73 & 72 & 22 & 16 & 1 & 0 \\
\hline
\end{tabular}

One-third of the specimens (three from each species) were infected with tissue fluid containing fifteen Salm. dublin bacteria', one-third with fifteen Salm. typhi-murium and the remainder with fifteen Salm. thompson.

Cultures were made from liquid desoxycholate-citrate medium on to plates of Wilson and Blair medium. The rest were cultured on to desoxycholate-citrate-agar.

The recovery of Salmonella pullorum and gallinarum from faeces by means of selenite and tetrathionate media

It was considered possible that more difficulty would be experienced in isolating some of the less typical members of the Salmonella genus such as Salm. pullorum and gallinarum from faeces. Accordingly, tissues naturally infected with these bacteria were used to carry out experiments similar to those with the more typical salmonellae, Salm. dublin, typhi-murium and thompson, using selenite and tetrathionate media. Since Salm. gallinarum infection is usually restricted to chickens, only faeces from these were used. A number of turkey faeces also were used in the case of Salm. pullorum but, since the results with them were no different from those with chicken faeces, only the results with faeces from the latter species are referred to below. The recovery of salmonellae by means of selenite and tetrathionate media from fifty specimens of chicken faeces to which had been added 
tissue fluid containing ten Salm. gallinarum bacteria, and the result of a similar experiment with Salm. pullorum is shown in Table 8 together with the total results when experiments on specimens not shown to be positive were repeated using inocula containing larger numbers $(20-100)$ of salmonellae. The solid medium was desoxycholate-citrate-agar. Comparison of the results with those for Salm. dublin, typhi-murium and thompson (Tables 1-4) shows that Salm. gallinarum and pullorum were more difficult to isolate from faeces when small inocula were used. However, when the inoculum was increased to 100 bacteria only two of the fifty specimens were still negative after selenite and four after tetrathionate enrichment in the case of Salm. gallinarum. The corresponding figures for Salm. pullorum were five and two respectively. When the inoculum contained ten salmonellae, tetrathionate was considerably superior to selenite, twelve positive results compared with two with Salm. gallinarum and twenty-two compared with

Table 8. The recovery of Salm. gallinarum and pullorum from chicken faeces by means of selenite and tetrathionate medium

\begin{tabular}{|c|c|c|c|c|}
\hline \multirow{2}{*}{$\begin{array}{l}\text { Faeces infected with tissue } \\
\text { fluid containing }\end{array}$} & \multirow{2}{*}{$\begin{array}{c}\text { No. of } \\
\text { salmonella } \\
\text { bacteria added }\end{array}$} & \multicolumn{3}{|c|}{$\begin{array}{c}\text { No. of } 50 \text { faecal specimens shown } \\
\text { to be positive by }\end{array}$} \\
\hline & & Selenite & Tetrathionate & Both media \\
\hline Salm. gallinarum & $\begin{array}{r}10 \\
20 \\
50 \\
100\end{array}$ & $\begin{array}{r}2 \\
41 \\
48 \\
48\end{array}$ & $\begin{array}{l}12 \\
25 \\
28 \\
46\end{array}$ & $\begin{array}{l}13 \\
46 \\
49 \\
50\end{array}$ \\
\hline Salm. pullorum & $\begin{array}{r}10 \\
20 \\
50 \\
100\end{array}$ & $\begin{array}{r}8 \\
13 \\
27 \\
45\end{array}$ & $\begin{array}{l}22 \\
25 \\
30 \\
48\end{array}$ & $\begin{array}{l}23 \\
31 \\
42 \\
48\end{array}$ \\
\hline
\end{tabular}

Cultures were made on desoxycholate-citrate-agar plates from the enrichment media.

eight with Salm. pullorum. The results with Salm. gallinarum were particularly interesting because when the inoculum was increased to twenty bacteria, best results were obtained with selenite, forty-one specimens being positive as compared with twenty-five by tetrathionate. This illustrates the marked effect that the individual variation of different faecal specimens has on the ability to isolate salmonellae from them. It also confirms the desirability of using both media in the routine examination of faeces.

The above experiments were repeated with thirty specimens of chicken faeces and inoculum of six bacteria from a broth culture of a laboratory strain of Salm. pullorum. This salmonella was recovered from twenty-one of the thirty faecal specimens by means of selenite and from twenty-five by means of tetrathionate medium confirming the observation made when comparing infected tissue fluid and a broth culture of Salm. dublin obtained from this material (see above) that inaccurate deductions can be made when cultures are used for the evaluation of culture media. 
The isolation of Salmonella cholerae-suis from faeces

The original experiments with tissue fluids containing Salm. dublin, typhimurium, and thompson using selenite and tetrathionate media were repeated with infected material containing approximately eight Salm. cholerae-suis bacteria. Positive results were not recorded from any of the 180 faecal specimens. The experiment was repeated with a larger inoculum of Salm. cholerae-suis, but the results were still negative. Tubes of selenite and tetrathionate to which faeces had not been added were now sown with tissue fluid containing approximately 10,000 of these bacteria. No visible growth occurred in either medium. Since it was possible that the strain of Salm. cholerae-suis was atypical, the latter experiment was repeated using twenty different laboratory strains; the results were still negative. Growth also did not occur in tubes of selenite medium containing $\frac{3}{4}, \frac{1}{2}$ and $\frac{1}{4}$ the normal amount of sodium hydrogen selenite, with or without faeces. Similar experiments were carried out with tetrathionate broth, controls in the form of cultures of Salm. dublin and thompson being kept as in the case of the selenite medium experiments. The control cultures grew quite well in broth containing up to $7.0 \mathrm{ml}$. of iodine solution and $14.0 \mathrm{ml}$. of sodium thiosulphate solution per $100 \mathrm{ml}$. of media. Growth did not occur with any of the Salm. cholerae-suis strains until the amounts of iodine and thiosulphate were reduced to 4.0 and $8.0 \mathrm{ml}$. respectively (better growth occurring with 3.5 and $7.5 \mathrm{ml}$. of each) in the absence of faeces. Negative results were also obtained with tetrathionate broth prepared according to the formula of Knox, Gell \& Pollock (1942), although some multiplication of Salm. cholerae-suis occurred when large inocula were used and faeces added.

It was decided to determine the most suitable medium for isolating Salm. cholerae-suis from faeces. Since infection with this bacterium is more common in pigs than other animals, twenty faecal specimens from pigs were used, with nine laboratory cultures as well as the infected tissue fluid referred to above; each strain was used to infect two faecal specimens. No important differences were noted between strains of the kunzendorf and American varieties so they are considered collectively. The enrichment media examined were selenite medium, tetrathionate broth $(3.5 \mathrm{ml}$. of iodine solution and $7.0 \mathrm{ml}$. of sodium thiosulphate solution per $100 \mathrm{ml}$. of broth) with and without the addition of 1/100,000 brilliant green, brilliant green peptone water, cacotheline broth, liquid Wilson and Blair medium and liquid desoxycholate-citrate medium. Cultures in these media after incubation were sub-cultured on to both desoxycholate-citrate-agar and brilliant green agar. The infected faeces were also cultured direct on to desoxycholatecitrate-agar, brilliant green agar, and Wilson and Blair solid medium. The results (Table 9) using inocula of approximately 30,000 and 3000 Salm. cholerae-suis bacteria showed that direct culture on to brilliant green agar was superior to all the other methods including the use of enrichment media. It was also markedly superior to desoxycholate-citrate-agar for culturing from enrichment media. Salmonellae were not recovered from any of the specimens by direct culture on Wilson and Blair solid medium or by enrichment in selenite medium. Enrichment 
in tetrathionate broth and liquid desoxycholate-citrate medium was only slightly inferior to direct culture on brilliant green agar when an inoculum of 30,000 bacteria was used, giving 14,11 and 15 positive results respectively. However, when the inoculum was reduced to 3000 bacteria, nine specimens were still shown to be positive by direct culture on brilliant green agar, but only two by tetrathionate broth and three by liquid desoxycholate-citrate medium.

\section{The ability of different species of salmonellae to grow in selenite and tetrathionate media}

In view of the results with Salm. cholerae-suis, 158 strains of salmonellae representing forty-eight different species were examined to determine whether they would grow in selenite and tetrathionate media. The two strains of Salm. paratyphi $A$ examined did not grow in tetrathionate medium, confirming the observation of Tabet (1949). Salm. abortus-equi strains appeared to grow poorly in tetrathionate broth. However, experiments using horse faeces and an inoculum of approximately fifteen bacteria from broth cultures of five laboratory strains,

Table 9. The use of different media in the recovery of Salmonella choleraesuis from infected pig faeces

\begin{tabular}{|c|c|c|c|c|c|c|c|c|c|c|}
\hline \multirow[b]{2}{*}{$\begin{array}{l}\text { No. of Salm. } \\
\text { cholerae-suis } \\
\text { bacteria added } \\
\text { to each faecal } \\
\text { specimen }\end{array}$} & \multicolumn{10}{|c|}{ No. of positive results (of 20 specimens) by } \\
\hline & $\begin{array}{c}\text { Brilliant } \\
\text { green agar }\end{array}$ & $\begin{array}{l}\text { Desoxy- } \\
\text { cholate- } \\
\text { citrate- } \\
\text { agar }\end{array}$ & $\begin{array}{c}\text { Solid } \\
\text { Wilson } \\
\text { Blair } \\
\text { medium }\end{array}$ & Selenite & $\begin{array}{l}\text { Tetra- } \\
\text { thionate }\end{array}$ & $\begin{array}{c}\text { Tetra- } \\
\text { thionate } \\
\text { brilliant } \\
\text { green }\end{array}$ & $\begin{array}{l}\text { Brilliant } \\
\text { green } \\
\text { peptone } \\
\text { water }\end{array}$ & $\begin{array}{c}\text { Caco- } \\
\text { theline } \\
\text { broth }\end{array}$ & $\begin{array}{l}\text { Liquid } \\
\text { desoxy- } \\
\text { cholate- } \\
\text { citrate }\end{array}$ & $\begin{array}{c}\text { Liquid } \\
\text { Wilson } \\
\text { Blair }\end{array}$ \\
\hline $\begin{array}{r}30,000 \\
3,000\end{array}$ & $\begin{array}{r}15 \\
9\end{array}$ & $\begin{array}{r}13 \\
5\end{array}$ & $\begin{array}{l}0 \\
0\end{array}$ & $\begin{array}{l}0(0) \\
0(0)\end{array}$ & $\begin{array}{r}14(4) \\
2(0)\end{array}$ & $\begin{array}{l}7(2) \\
0(0)\end{array}$ & $\begin{array}{l}8(0) \\
1(0)\end{array}$ & $\begin{array}{l}2(2) \\
1(0)\end{array}$ & $\begin{array}{r}11 \\
3\end{array}$ & $\begin{array}{l}4(0) \\
0(0)\end{array}$ \\
\hline
\end{tabular}

Ten different strains of Salm. cholerae-suis were used, one for each pair of faecal specimens. The results using enrichment media a
citrate-agar being shown in parentheses.

no naturally-infected material being available, showed that it was possible to recover these salmonellae satisfactorily by means of tetrathionate as well as selenite medium. Three of twelve strains of Salm. enteritidis grew poorly in tetrathionate medium. Experiments revealed that it was impossible to recover these three strains from cow faeces unless they were added in numbers of between 200 and 1000 bacteria. The remaining nine strains were recoverable with the smallest inoculum tested, forty bacteria. The five strains of Salm. abortus-ovis examined grew poorly in selenite and tetrathionate media, as also in ordinary media such as nutrient broth. Colonies on desoxycholate-citrate-agar were small, little more than of pin-point size after 24 hours' incubation. No growth was observed on brilliant green agar or Wilson and Blair solid medium. Experiments with these five strains and ten specimens of sheep faeces showed that, with an inoculum of 20,000 bacteria, positive isolations were made from five of the ten specimens by direct culture on desoxycholate-citrate-agar, three after selenite enrichment, and five after tetrathionate enrichment. The corresponding figures for an inoculum of 3000 bacteria were four, none and one respectively. No positive results were obtained with either inoculum when cacotheline broth, liquid desoxycholate-citrate medium, liquid Wilson and Blair medium, or brilliant green peptone water were used.

The remainder of the 158 strains of salmonellae grew prolifically in selenite and tetrathionate media. 


\section{DISCUSSION}

The most interesting observation was the extreme sensitivity of selenite and tetrathionate media for recovering salmonellae from the faeces of all the nine species of animals examined and their definite superiority over other enrichment media. More positive results were obtained when both media were used but if one only were used there were indications that selenite was best for one species of animal, tetrathionate for another and for others there was little difference. Taken as a whole, selenite was slightly superior to tetrathionate medium, confirming the observations of Hobbs \& Allison (1945), Cruickshank \& Williams Smith (1949), Ruys \& Van der Plaats (1949), Cook, Frisby \& Jebb (1951), Williams Smith \& Buxton (1951) and others. Apart from the different effects of faeces from different animal species upon the efficiency of selenite and tetrathionate media, faeces from animals of the same species also differed from one another in this respect, while different species of Salmonella, and even different strains of one species, as the twelve strains of Salm. enteritidis, did not behave alike. However, these differences only mattered when inocula containing very small numbers of salmonellae were added to the faecal specimens. When the inoculum was increased to about 100 bacteria they were no longer observed.

Since direct plating would only detect salmonellae frequently when as many as 2000 or 20,000 were added to the faeces, direct plating is probably not worth while when seeking symptomless excreters, except for Salm. cholerae-suis and Salm. abortus-ovis for which no suitable enrichment media exist. This suggestion is not meant to call in question the value of direct plating in the examination of material from clinically sick subjects, when direct plating may not only expedite diagnosis, but also give an indication of the degree of infection.

Salm. cholerae-suis and abortis-ovis are probably unique among the salmonellae in that direct plating is superior to enrichment culture in their isolation from faeces. In the case of Salm. abortus-ovis this is probably related to a slow rate of multiplication in all culture media rather than to any toxic effect of selenite and tetrathionate. Slavin (1943) found that direct culture on brilliant green agar was better than on MacConkey's agar, or in Muller's tetrathionate broth or brilliant green peptone water for culturing Salm. cholerae-suis from pig faeces, and the present work indicates that the more modern media are also unsuitable. The reason, however, is not primarily that pig faeces contain bacteria which outgrow salmonellae but that many of the media used are too toxic to permit the growth of Salm. cholerae-suis. In this respect it was noted that Salm. cholerae-suis was also difficult to cultivate from the faeces of species of animals other than pigs while other salmonellae were quite easy to recover from pig faeces. The inability of Salm. cholerae-suis to grow in the more modern enrichment media is a serious handicap to the study of the epidemiology of disease caused by this organism and may account for some of the observations that healthy faecal excreters are rare (Edwards, Bruner \& Moran, 1948; Saphra, 1950).

The observation that 24-30 hr. was the best incubation time for tetrathionate medium appeared to conflict with the observation of Fry (see Hobbs \& Allison, 
1945), who found a much shorter time more suitable. However, this may have been because the faecal specimens he examined were heavily infected, so that the salmonellae would have attained an optimal concentration in the medium much more quickly than they would in my very lightly infected specimens. The significant observation in both cases was that a much smaller number of specimens was shown to be positive after this optimum time. Since, under practical conditions, the salmonella content of any specimen is unknown it is obvious that to achieve the best results tetrathionate-enriched specimens should be cultured on to solid media after more than one time interval (Boecker, 1935; Waldhecker, 1935). This would not appear to be so necessary in the case of selenite medium since, after the optimal incubation time was reached, the number of positive specimens did not decrease.

The results obtained by streaking cultures of different types of salmonellae in selenite medium on to solid Wilson and Blair medium confirm the observation of Hobbs \& Allison (1945) on Salm. typhi and Cook et al. (1951) on Salm. paratyphi $B$ that this combination of media may inhibit the growth of salmonellae as well as other bacteria. This indicates that reliance on this combination alone would cause many positive specimens to be missed.

\section{SUMMARY}

The sensitivity of different culture media for isolating salmonellae from the faeces of man, dog, horse, cow, sheep, pig, chicken, duck and turkey has been investigated. Suitable dilutions of tissue fluids of animals that had died from salmonella infection, and in which the numbers of viable salmonellae could be accurately estimated, had previously been added to the faecal specimens. Tissue fluids containing Salmonella dublin, typhi-murium, thompson, cholerae-suis, gallinarum and pullorum were used.

Selenite and tetrathionate media were greatly superior to liquid desoxycholatecitrate medium, liquid Wilson and Blair medium, cacotheline broth and brilliant green peptone water. By the use of either selenite or tetrathionate media it was usually possible to recover salmonellae from faecal specimens to which less than ten salmonellae had been added. They could nearly always be recovered from specimens containing 100 salmonellae.

Salmonellae were more easily recovered from the faeces of some species of animals than others. For selenite, the order of ease of recovery was horse, followed by sheep, human, cow, chicken, pig, turkey, dog and duck faeces, and for tetrathionate, horse, sheep, human, dog, pig, cow, turkey, chicken and duck faeces.

Selenite medium was preferable to tetrathionate for examining cow and chicken faeces but the reverse was true in the case of dog faeces; slight differences only were noted in the other species. Taken as a whole, selenite was slightly superior to tetrathionate, but best results were obtained by the use of both media.

Some types of salmonellae were easier to recover from faeces than others. Of six salmonella types, Salm. thompson was easiest to recover followed by Salm. typhi-murium, dublin, gallinarum, pullorum and cholerae-suis, in that order. 
Erroneous results were obtained when laboratory cultures were used instead of infected tissue fluids.

It was necessary to add several thousand salmonellae to faeces before they could be recovered by direct culture on desoxycholate-citrate-agar or Wilson and Blair solid medium.

Salm. cholerae-suis and Salm. abortus-ovis were exceptional in that direct plating was superior to the use of enrichment media.

With lightly infected specimens an incubation period of 24-30 hr. was optimum for selenite and tetrathionate media. A longer period was detrimental with tetrathionate but not with selenite medium.

The combination of selenite and solid Wilson and Blair medium was sometimes too inhibitory to permit the growth of salmonellae.

There was little advantage in preparing selenite medium with mannitol instead of lactose.

Thanks are due to Miss J. Gavins and Mr K. A. Piggins for excellent technical help. I am also grateful to Messrs Blaxland, Buxton, Field, Gibson, Jordan, Dr G. Slavin and Dr Joan Taylor for providing much of the material used in this work.

\section{REFERENCES}

BoECker, E. (1935). Z. Hyg. InfektKr. 117, 679.

Cook, G. T., Frisby, B. R. \& JeBB, W. H. H. (1951). Mon. Bull. Min. Hlth Publ. Hlth Lab. Serv. 10, 89.

Crútckshank, J. C. \& Williams Smith, H. (1949). Brit. med. J. ii, 1254.

Edwards, P. R., Bruner, D. W. \& Moran, A. B. (1948). J. infect. Dis. 83, 220.

Fenner, F., Martin, S. P. \& Pierce, C. H. (1949). Ann. N.Y. Acad. Sci. 52, 751.

Hatnes, R. B., Elliot, E. M. L. \& Tomlinson, A. J. H. (1947). Spec. Rep. Ser. med. Res. Coun., Lond., no. 260.

Hoвbs, B. C. \& Allison, V. D. (1945). Mon. Bull. Min. Hlth Publ. Hlth Lab. Serv. 4, 12, 63.

Hynes, M. (1942). J. Path. Bact. 54, 193. .

Jones, R. E. \& Handiey, W. R. C. (1945). Mon. Bull. Min. Hlth Publ. Hlth Lab. Serv. 4, 107.

Knox, R., Gell, P. G. H. \& Pollock, M. R. (1942). J. Path. Bact. 44, 469.

Leifson, E. (1935). J. Path. Bact. 40, 581.

Leifson, E. (1936). Amer. J. Hyg. 24, 423.

Miles, A. A. \& Misra, S. S. (1938). J. Hyg., Camb., 38, 732.

Rolfe, V. (1946). Mon. Bull. Min. Hlth Publ. Hlth Lab. Serv. 5, 158.

Ruys, A. C. \& Van der PlaAts, A. B. J. (1949). Antonie van Leuwenhoeck J. Microbiol. Serol. $15,91$.

SAPHRA, J. (1950). Amer. J. med. Sci. 220, 74.

Slavin G. (1943). J. comp. Path. 53, 315.

TABET, F. (1949). J. R. Egypt. med. Assoc. $1,1$.

WALDHECKER, M. (1935). Z. Hyg. InfektKr. 117, 679.

Wirliams Smith, H. \& Buxton, A. (1951). Brit. med. J. i, 1478.

Wilson, W. J. \& Blair, E. M. McV. (1931). J. Hyg., Camb., 31, 138.

(MS. received for publication 16. vII. 51.) 